\title{
ПРАВОВЕ СТАНОВИЩЕ СІМЕЙНИХ ФЕРМЕРСЬКИХ ГОСПОДАРСТВ
}

Сокол М. В.

У науковій статmі досліджено правове регулювання створення та функціонування сімейних фермерських господарств. Наводиться типологія фермерських господарств та виділяються їх специфічні ознаки. Проаналізовано низку законодавчих актів та наукових праць, і зроблено висновок, що схожість правового становища та можливість набуття статусу сімейних фермерських господарств, котрі діятимуть на підставі реєстрації фізичної особи - підприємця, стосується лише тих особистих селянських господарств, діяльність яких спрямована на реалізацію надлишків продукції. Тобто в майбутньому їхнє функціонування буде пов'язано з виробництвом товарної сільськогосподарської продукціі. Внесено пропозиції щодо зміни вимог до сімейного фермерського господарства без статусу юридичної особи як платника податку четвертої групи спрощеної системи оподаткування.

Ключові слова: аграрне право, фермерське господарство, сімейне фермерське господарство, сімейне фермерське господарство без статусу юридичної особи.

В статье исследовано правовое регулирование создания и функционирования семейных фермерских хозяйств. Приводится типология фермерских хозяйств и выделяются их специфические признаки. Проанализирован ряд законодательных актов и научных трудов, и сделан вывод, что сходство правового положения и возможности дальнейшего приобретения статуса семейных фермерских хозяйств, которые будут действовать на основании регистрации физического лица - предпринимателя, касается только тех личных крестьянских хозяйств, деятельность которых направлена на реализацию излишков продукции. То есть в будущем их функционирование будет связано с производством товарной сельскохозяйственной продукции. Внесены предложения по изменению требований к семейному фермерскому хозяйству без статуса юридического лица как налогоплательщика четвертой группы упрощенной системы налогообложения.

Ключевые слова: аграрное право, фермерское хозяйство, семейное фермерское хозяйство, семейное фермерское хозяйство без статуса юридического лица.

Sokol M. V. Legal status of family farms

The article analyzes the legal regulation of the establishment and operation of family farms. There are three types of farms: farm that has the status of a legal entity, a farm that has the status of a family-type legal entity, a family farm that does not have the status of a legal entity.

Specific features of family farms are: 1. farm may include members of the same family who live together, 2. the head of the family farm can be only a member of this family, 3. the use of labor of employees is allowed only for performance of seasonal and individual works that are directly related to the activities of farm and require special knowledge or skills, 4. conducting farming activities on land plots given to them in ownership or use on lands intended for the introduction of farming, personal farming and commodity agricultural production, 5 . the condition of registration is the conclusion of a new type of agrarian-legal agreement on the establishment of a family farm.

(с) Сокол М. В., 2020
The advantages of personal farming in comparison with family farming are given. Private farms may use for production only small plots of land provided for their activities, in contrast, farmers have the right to use land provided for both farming and personal farming, and commodity agricultural production. These entities are not equal participants in the agricultural market, and do not have the status of agricultural producers. Also, members of peasant farms are not insured persons. An equally important aspect is the availability of existing programs of budget support for the agricultural sector, which is currently possible only for natural persons - entrepreneurs who have the status of a family farm.

A number of legislative acts and scientific works are analyzed and it is concluded that the similarity of legal status and the possibility of further acquisition of the status of family farms, which will operate on the basis of registration of a natural person entrepreneur applies only to those personal farms whose activities are aimed at surplus in the future, their operation will be associated with the production of marketable agricultural products. Proposals have been made to change the requirements for a family farm without the status of a legal entity as a taxpayer of the fourth group of the simplified taxation system.

Key words: agricultural law, farm, family farm, family farm without legal entity status.

Постановка проблеми та її актуальність. В умовах розвитку аграрної економіки України чільне місце на сьогодні займають дрібні господарства, які $\epsilon$ виробниками основної частки сільськогосподарської продукції. До таких організаційно-правових форм підприємницької діяльності належать сімейні фермерські господарства (далі - СФГ), що маю статус і юридичної особи, і фізичної особи - підприємця. У європейських державах такі суб'єкти аграрних правовідносин відіграють важливу соціально-економічну та культурну роль, і, як досить доречно зазначає П. Кулинич, виступають носіями сільського способу життя [1, с. 49].

В українському законодавстві правовий статус сімейних фермерських господарств визначений Законом України «Про фермерське господарство» від 19.06.2003 р. [2] та Законом України «Про внесення змін до Податкового кодексу України та деяких законів України щодо стимулювання утворення та діяльності сімейних фермерських господарств» від 10.07.2018 р. [3]. Проте, незважаючи на детальну регламентованість законодавчого порядку діяльності сімейних фермерських господарств, залишається досить багато невирішених питань щодо порядку створення та державної реєстрації таких суб'єктів, а також сплати ними єдиного податку четвертої групи спрощеної системи оподаткування.

Аналіз останніх досліджень і публікацій. Теоретичні та практичні аспекти становлення та розвитку таких організаційно-правових форм підприємницької діяльності висвітлювалися у працях таких науковців: В. Єрмоленка, В. Жушмана, Г. Корнієнка, П. Кулинича, С. Лушпаєва, О. Погрібного, А. Статівки, Н. Титової, В. Уркевича, С. Хрипко, М. Шульги та інших. 


\section{Проблеми цивільного та господарського права}

Метою статті $є$ дослідження типології фермерських господарств, їх ознак, а також розгляд особливостей державної реєстрації та оподаткування сімейних фермерських господарств.

Виклад основного матеріалу. Основним напрямом спільної аграрної політики України та $€ С €$ підтримка сімейних фермерських господарств, які виробляють широкий спектр сільськогосподарської продукції й забезпечують добробут членів відповідної родини. На думку законодавця, чітке регулювання правового становища цих суб'єктів аграрних правовідносин сприятиме розвитку організованого сільськогосподарського виробництва шляхом збільшення кількості офіційних суб'єктів аграрного ринку й урегулювання правил їх діяльності в цій сфері, що, зі свого боку, сприятиме усуненню податкових перешкод у їх діяльності та зростанню доходів сільського населення загалом [4]. Проте в наукових колах точаться дискусії щодо необхідності створення сімейних фермерських господарств та ототожнення їх з особистими селянськими господарствами (далі - ОСГ).

Так, на думку Г. Корнієнка, такі зміни в законодавчому полі не тільки вносять плутанину до визначення фермерського господарства, але і сприяють ототожненню його з особистим селянським господарством [5, с. 131]. За твердженням С. Хрипко, ці новели спрямовані на приєднання особистих селянських господарств до фермерських господарств [6, с. 37]. Наукова позиція щодо ототожнення ОСг із сімейним фермерським господарством без статусу юридичної особи підтримується також і С. Лушпаєвим [7, с. 108]. Взявши до уваги наведені аргументи, варто зауважити, що, безспірно, вищезазначені суб'єкти аграрних правовідносин мають низку спільних ознак, проте їх ототожнення чи повне перетворення вважається не зовсім доречним. У цьому разі варто погодитись із позицією О. Гафурової, на думку якої нововведення в законодавчій сфері діяльності фермерських господарств створюють умови для наближення правового становища сімейного фермерського господарства, організованого на основі діяльності фізичної особи - підприємця, до правового становища ОСГ [8, с. 282].

Як влучно зазначає дослідниця, що мета діяльності зазначених господарств $\epsilon$ різною (в ОСГ - це задоволення особистих потреб його членів; у ФГ - отримання прибутку), але засоби іï досягнення не надто відрізняються: для ОСГ - це здійснення виробництва, переробки і споживання сільськогосподарської продукції, а також реалізація іï надлишків; для ФГ - виробництво товарної сільськогосподарської продукції, здійснення iï переробки та реалізації. Тобто в обох випадках - це реалізація товарної сільськогосподарської продукції. На підставі цього, на думку О. Гафурової, необхідно вимагати уніфікації вказаних правовідносин [8, с. 282]. Безспірно, що наявність частково ідентичних ознак ОСГ й СФГ наближує їх правове становище один до одного, проте не варто забувати про споживчий характер діяльності ОСГ, яке може виготовляти продукцію лише для власного споживання або частково реалізовувати надлишки вирощеної продукції (і то лише в обмежених розмірах - не більше 50-ти розмірів мінімальних заробітних плат на рік), крім того, доходи повинні бути отримані від продажу власної сільськогосподарської продукції, яка $є$ вирощена, відгодована, виловлена, зібрана, виготовлена, вироблена, оброблена та/або перероблена безпосередньо фізичною особою на земельних ділянках, що надані для ведення ОСГ в розмірі, який не перевищує 2-х га [9].

Узагальнюючи наведене вище, варто зауважити, що схожість правового становища та можливість набуття статусу сімейних фермерських господарств, які діятимуть на підставі реєстрації фізичної особи - підприємця, стосується лише тих особистих селянських господарств, діяльність яких спрямована на реалізацію надлишків продукції, тобто в майбутньому їхнє функціонування буде пов'язано з виробництвом товарної сільськогосподарської продукції.

Світовий досвід показує, що основу аграрного сектору країн із розвинутою ринковою економікою становлять сімейні ферми. Фермерське господарство - це ринково орієнтована підприємницька структура, яка має досить великі земельні наділи для виготовлення товарної сільськогосподарської продукції, може займатись їі переробленням і реалізацією. За даними статистичних досліджень, проведених на різних континентах, із понад 570 млн ферм більше 500 млн належать саме сім'ям. На сімейні ферми припадає не менше 56\% виробленої сільгосппродукції. Такі господарства обробляють значну частку сільгоспземель у світі: $83 \%$ - в Північній і Центральній Америці, 68\% - у Європі, 85\% - в Азії, $62 \%$ - в Африці. І тільки в Південній Америці ця частка становить $18 \%$ [10].

Зважаючи на розвиток сімейних ферм в інших країнах та правову позицію українського законодавця, діяльність тих ОСГ, які спрямовані на виробництво товарної сільськогосподарської продукції, не $\epsilon$ перспективною, порівняно із СФГ. Адже вони можуть використовувати для виробництва продукції лише невеликі земельні наділи, надані для ведення ОСГ, на противагу цьому СФГ мають право користуватись землями, наданими для ведення як фермерського господарства, так і особистого селянського господарства, так і товарного сільськогосподарського виробництва. Ці суб'єкти не $\epsilon$ рівноправними учасниками аграрного ринку, оскільки ОСГ не мають статусу виробника сільськогосподарської продукції. Ще однією перевагою СФГ перед ОСГ $\epsilon$ наявність обов'язкового соціального страхування. Цієї миті членів особистого селянського господарства вважають зайнятим населенням, якщо така діяльність для них $є$ основною. Тобто отримувати допомогу по безробіттю чи, надалі, пенсійне забезпечення вони можуть лише на підставі добровільного соціального страхування. Не менш важливим аспектом також $\epsilon$ доступність до чинних програм бюджетної підтримки аграрного сектору, яка нині $€$ можливою лише для фізичних осіб - підприємців, які мають статус сімейного фермерського господарства.

Обговорюючи перспективу приєднання ОСГ до фермерського господарства, науковці одразу виділяють декілька типів останніх. С. Хрипко вважає доцільним виокремити 3 типи таких суб'єктів господарювання:

1) фермерське господарство, зареєстроване як юридична особа;

2) індивідуальне фермерське господарство;

3) фермерське господарство сімейного типу [6, с. 37].

Зі свого боку, П. Кулинич акцентує увагу на додаткових трьох різновидах фермерських господарств сімейного типу: ті, які мають статус юридичної особи, без такого статусу та індивідуальні [1, с. 49]. В. Поліщук 
називає 4 форми фермерського господарства, а саме: фермерське господарство - юридична особа, сімейне фермерське господарство - юридична особа, фермерське господарство - фізична особа-підприємець, сімейне фермерське господарство - фізична особа-підприємець [11, с. 68].

Зважаючи на наукове тлумачення ст. 1 Закону України «Про фермерське господарство» та на підставі низки відокремлених ознак, уважається за доцільне виділити 3 типи фермерських господарств:

фермерське господарство, котре має статус юридичної особи, членами такого господарства можуть виступати близькі родичі та свояки, незалежно від місця їх проживання, також ця організаційно-правова форма може здійснюватися індивідуально однією особою;

фермерське господарство, що має статус юридичної особи сімейного типу, до складу якого входять члени однієї сім'ї, котрі спільного проживають, пов'язані побутом та мають спільні права й обов'язки;

сімейне фермерське господарство, яке не має статусу юридичної особи. В підприємницькій діяльності такого господарства використовується праця членів, якими $є$ виключно члени однієї сім'ї, відповідно до ст. 3 Сімейного кодексу України. Фермерське господарство без статусу юридичної особи, яке організовується на основі діяльності ФОП, може мати й індивідуальний характер.

Безспірними правовими ознаками сімейних ферм $є$ :

1. Використання під час здійснення господарської діяльності праці виключно членів такого господарства - членів однієї сім'ї. Ч. 5 ст. 1 ЗУ «Про фермерське господарство» має банкетний характер, конкретний iї зміст розкривається у ст. 3 Сімейного кодексу, де зазначено, що сім'ю становлять особи, які спільно проживають, пов'язані спільним побутом, мають взаємні права та обов'язки [12]. Виникає запитання, чи можуть бути членами сімейного фермерського господарства дорослі неодружені діти або діти, які створили власні сім'ї, але проживають спільно із батьками.

У правовій доктрині сімейного права наявний такий різновид сімей, як складна, або розширена сім'я. Тобто йдеться про такі собі квазісімейні утворення, які складаються з багатьох сімейних пар та поколінь. Це означає, що до складу сімейного фермерського господарства можуть уходити всі особи, які спільно проживають та відповідають іншим ознакам, передбаченим у ч. 2 ст. 3 Сімейного кодексу України.

Крім того, якщо хтось із подружжя або дитина від 14 років тимчасово не проживає спільно через відповідні обставин (лікування, робота, навчання), це не позбавляє їх членства в сімейному фермерському господарстві.

2. Головою сімейного фермерського господарства може бути лише член цієї сім’ї. Окремо в Законі України «Про фермерське господарство» ст. $8^{1}$ передбачено, що сімейне фермерське господарство без статусу юридичної особи створюється на підставі оформлення голови господарства як фізичної особи підприємця [2, ст. $\left.8^{1}\right]$.

Проводячи аналіз цієї норми, варто зауважити, що особа отримує статус голови фермерського господарства не лише у віці 18 років, як це передбачено вищезгаданим Законом. Реєстрація фермерського господарства сімейного типу фізичною особою - підприємцем, який надалі може набувати статусу голови фермерського господарства, здійснюється із 16-тирічного віку. У зв'язку із цим варто внести зміни до ч. 1 ст. 5 Закону України «Про фермерське господарство» й передбачити, що право на створення фермерського господарства має кожен дієздатний громадянин України, який досяг віку 16 років.

3. Використання праці найманих працівників дозволяється виключно для виконання сезонних та окремих робіт, які безпосередньо пов'язані з діяльністю господарства й потребують спеціальних знань чи навичок.

4. Для реєстрації сімейного фермерського господарства, незалежно від того, $є$ статус юридичної особи чи ні, необхідно подати правовстановлюючі документи на землю або договір оренди землі. Варто наголосити на тому, що законом передбачена можливість ведення фермерської діяльності на земельних ділянках, наданих їм у власність, чи користування на землях, призначених для введення ФГ, ОСГ та товарного сільськогосподарського виробництва.

5. Обов'язковою умовою діяльності СФГ, яка діє на підставі реєстрації фізичної особи - підприємця, $є$ укладення нового виду аграрно-правового договору про створення сімейного фермерського господарства або укладення декларації у разі, якщо таке господарство буде вестись одноосібно.

Уведення до переліку суб'єктів аграрних правовідносин нового сільськогосподарського товаровиробника змушує законодавця вносити зміни до низки нормативно-правових актів, які тією чи іншою мірою регулюють його діяльність. Так, у 2018 році були внесені зміни до Податкового кодексу України, відповідно до яких суб'єктом - платником четвертої групи спрощеної системи оподаткування вперше було визначено фізичну особу - підприємця, який набув статусу сімейного фермерського господарства.

Відповідно до п. 291.4 Податкового кодексу України до 4-ї групи належать сільськогосподарські товаровиробники, зокрема фізичні особи - підприємці, які провадять діяльність виключно в межах фермерського господарства, за умови виконання сукупності таких вимог:

- здійснюють виключно вирощування, відгодовування сільськогосподарської продукції, збирання, вилов, переробку такої власновирощеної або відгодованої продукції та її продаж;

- провадять господарську діяльність (крім постачання) за місцем податкової адреси;

- не використовують працю найманих осіб;

- членами фермерського господарства такої фізичної особи є лише члени їі сім'ї;

- площа сільськогосподарських угідь та/або земель водного фонду у власності та/або користуванні членів фермерського господарства становить не менше 2-х гектарів, але не більше 20-ти гектарів [9].

На практиці виникають суперечливі питання щодо обсягу площ земельних ділянок та місця їх розташування. Так, якщо у власності членів сімейного фермерського господарства $€ 25$ га землі, 5 із яких - це сіножаті або пасовища, чи така земля в такому обсязі визнана у встановленому порядку малопродуктивною й підлягає залуженню, або вона $\epsilon$ переданою в оренду, тобто не використовується в господарській діяльності фермерського господарства - це $\epsilon$ підставою для відмови в отриманні сімейним фермерським господарством 
статусу платника єдиного податку 4-ї групи. Вважаємо, що відповідна редакція правової норми обмежує право фізичної особи - суб'єкта підприємницької діяльності на обрання бажаного способу оподаткування. У зв'язку із цим названу вимогу варто викласти з таким формулюванням: «площа сільськогосподарських угідь та/ або земель водного фонду, які використовуються для здійснення господарської діяльності та перебувають у власності та/або користуванні членів фермерського господарства, становить не менше 2-х та не більше 20-ти гектарів».

Ще одна імперативна норма Податкового кодексу передбачає необхідність здійснення господарської діяльності за місцем податкової адреси. Місцем податкової адреси є саме місце проживання платника податку, тобто це, перш за все, конкретна адміністративно-територіальна одиниця (місто, селище, село). Сільськогосподарська діяльність же здійснюється за місцем знаходження земельної ділянки, яка може бути розташована як у межах населеного пункту, так і за його межами, тобто місце розташування земельної ділянки та, відповідно, ведення господарської діяльності фермерським господарством не завжди збігається 3 податковою адресою платника податку, що також і собі $\epsilon$ не зовсім правильним обмеженням прав СФГ на вибір спрощеної системи оподаткування.

Проведений аналіз свідчить, що Україна, дотримуючись напряму євроінтеграції, розвиває та вдосконалює аграрне законодавство шляхом закріплення правового статусу нових суб'єктів аграрних правовідносин - сімейних фермерських господарств. Проте все ж у таких нововведеннях наявні окремі дефекти правового регулювання створення та функціонування такої специфічної організаційно-правової форми господарської діяльності.

\section{Література}

1. Кулинич П. Сімейні фермерські господарства у виробничій інфраструктурі сільських територій України: правові проблеми створення та діяльності. Актуальні проблеми екологічних, земельних та аграрних правовід носин: теоретико_методологічні й прикладні аспекти: Матеріали «круглогостолу», М. Харків, 5 грудня 2014 р. Харків, 2014. С. 47-50.
2. Про фермерське господарство: Закон України від 19.06.2003 р. № 973-IV. Відомості Верховної Ради України. 2003. № 45. СТ. 363.

3. Про внесення змін до Податкового кодексу України та деяких законів України щодо стимулювання утворення та діяльності сімейних фермерських господарств : Закон України від 10.07.2018 р. № 2497-VIII. Відомості Верховної Ради України. 2018. № 37. СТ. 276.

4. Про внесення змін до деяких законів України щодо стимулювання створення та діяльності сімейних фермерських господарств : Пояснювальна записка до проєкту Закону України від 23.12.2014 р. URL: http://w1.c1.rada.gov.ua/ pls/zweb2/webproc4_1?pf3511 =53102.

5. Корнієнко Г. Щодо можливих змін до Закону України «Про фермерське господарство». Сучасні тенденції та перспективи розвитку аграрного, земельного і екологічного права : Матеріали Всеукр. наук.-практ. конф., присвяченої 90-річчю від народження академіка В. Янчука (м. Київ, 22-23 травня 2015 р.). Київ, 2015. С. 129-131.

6. Хрипко С. Сімейні фермерські господарства: проблеми правового регулювання. Підприємництво, господарство і право. 2015. № 9. С. 36-39.

7. Лушпаєв С. Правове становище сімейного фермерського господарства: окремі питання. Підприємництво, господарство і право. 2017. № 3. С. 107-110.

8. Гафурова О. Проблеми правового регулювання діяльності особистих селянських господарств. Часопис Київського університету права. 2016. № 3. С. 280-284.

9. Податковий кодекс України від 02.12.2010 p. № 2755-VI. URL: https://zakon.rada.gov.ua/laws/show/ 2755-17\#Text.

10. Беззуб I. Перспективи розвитку сімейних фермерських господарств в Україні. URL: http://nbuviap.gov.ua/ index. php?option=\%20com_ content\&view=article\&id=419:ag ropromislovij-sektor2\&catid $=8 \&$ Itemid $=350$.

11. Поліщук В. Суб'єкти правовідносин у промисловому садівництві. Підприємництво, господарство і право. 2016. № 10. С. 66-70.

12. Сімейний кодексУкраїнивід 10.01.2002 p. №2947-III. Відомості Верховної Ради України. 2002. № 21-22. Ст. 135.

Сокол М. В., кандидат юридичних наук, доцент, доцент кафедри цивільно-правових дисциплін Східноєвропейського національного університету імені Лесі Українки 